driven to appeal to the public as well as to our own profession.

We trust that our appeal will meet with a liberal response both from the public and from the medical profession, for unless fresh funds are quickly forthcoming it will be impossible to continue the relief which is so urgently required.-We are, Sir, yours faithfully,

JoHN TwEEDY, President.

SAMUEL WeST, Hon. Treasurer.

G. Newton YItT, Hon. Secretary.

11, Chandos-street, Cavendish-square,

London, W., July 1st, 1916.

\section{THE MEDICAL DIRECTORY.}

To the Editor of THE LANCET.

SrR, - Our annual circular has been posted to the profession to-day. In view of the difficulties in obtaining labour, we are most anxious to have returns made to us as promptly as possible. We hope that practitioners who are serving in the navy and army will have arranged for their circulars to be forwarded to them.

We are, Sir, yours faithfully,

July 4th, 1916.

$$
\text { J. AND A. ChurChill. }
$$

\section{WOMEN STUDENTS AT THE LONDON HOSPITALS.}

To the Editor of THE LANCET.

SIR,-I note that in your issue of July 1st Professor W. D. Halliburton states "that St. George's Hospital has made a step forward in admitting a limited number of women students to 'their' wards, and that the experiment has proved such a complete success that he is hopeful that other hospitals will follow their example." Professor Halliburton, however, does not mention the fact, of which he is doubtless aware, that St. Mary's Hospital has already thrown open its doors to women students at the request of the authorities of the London School of Medicine for Women.

Since May 1st women students have been admitted to the wards of St. Mary's Hospital for clinical instrucrion, and at the present time 12 are working there. This number, it is expected, will be largely augmented in October. No request was made for admission of women students to courses of instruction in preliminary or intermediate subjects.

In justice to St. Mary's Hospital Medical School, I have thought it my duty to place these facts before you.

I am, Sir, yours faithfully,

JoHN F. H. BROADBENT,

July 3rd, 1916. Dean of St. Mary's Hospital Medical School.

\section{SPINAL AN RSTHESIA, WITH REFERENCE TO ITS USE IN THE TRENDELENBURG POSITION.}

\section{To the Editor of THE LANCET.}

Sir,-Will you allow me to add the following remarks to my paper on the above subject in answer to $\mathbf{M r}$. A. G. Stewart's letter, which appeared in your issue of June 24th?

In the case of the child aged 3 the injection was made in the third lumbar space; in the others in the second lumbar space. I was aware of the continental work done in relation to this position, and I heard Professor Jonnesco give his interesting lecture on high spinal anæsthesia at the Royal Society of Medicine in 1909, and, of course, did not mean to claim any originality. As to the general anæsthetic given in combination, I have used spinal anresthesia in the dorsal position in many abdominal operations without any general anæsthetic, but our object in these cases in giving a very small amount of general anæsthetic was to prevent psychic shock and to a a way with the discomfort of the position.

I am, Sir, yours faithfully,

July 3rd, 1916

H. M. PAGE.

\section{ALIMENTARY REST IN DIABETES.}

To the Editor of THE LANCET.

SIR,-Your leading article in to-day's issue does very scant justice to F. M. Allen. Allen bases his methods of treatment upon experimental work on animals and not upon hypotheses; in this it differs from that of Guelpa. Many of his followers have taken but a few steps along his path and failed to see the goal. The word "drastic" when applied to a treatment is misleading. The prolonged fast is an essential part of the treatment, and any case which is not submitted to alimentary rest until sugar disappears from the urine has not been treated by Allen's method and should not be included in records under that heading. The reason for the fast is not that it leads to the disappearance of sugar from the urine-that observation is simply a convenient method of determining that the fast has been of sufficient duration-but that it leads to an alteration in metabolism which permits a greater katabolism of carbohydrates. In my experience the severe cases prove the value of the method, the chronic cases yield to treatment which does not test so severely the control of the patient.

Although many hundreds of cases have been treated in America, many suffering from severe disease, with most happy results, let us wait until we have more evidence before we pass judgment, but do not let us prejudice the case by asserting that the treatment is of less value in severe cases than in mild. - I am, Sir, yours faithfully,

Portland-place, W., July lst, 1916.

O. LEYTON.

\section{THE STRETCHING OF SCAR TISSUES IN MOUTH LESIONS. \\ To the Editor of $\mathrm{THE} \mathrm{LANCE}$.}

SIR, - The description of a simple device for stretching scar tissue associated with mouth lesions may perhaps be of some value at the present moment. Its use applies particularly to those cases where the lip and cheek are bound down by scar tissue to the subjacent structures. The apparatus consists of a ring made with rubber tubing into which wire is introduced, the free ends of the tubing being fastened together to form a complete ring. The ring is placed between the lip and cheek on the one side and the gum, supported by bone on the other side in such a manner as to bring pressure to bear upon the scar tissue. By increasing the size of the tubing and the tension of the wire the pressure can be increased without causing discomfort to the patient beyond the presence of the apparatus. No. 8 size of tubing has been used most frequently at the commencement. The wire used is similar to that used as a driving cord for dental engines; it is twisted spirally. The ends of the tubing are fastened together with rubber solution, one end being made to overlap the other.

Previous to the introduction of this apparatus I had for some years been using pads of cotton-wool and simple tubing which has not been strengthened, but used chiefly in a $U$ form. The chief use formerly has been to free the lip in cases of hare-lip. The method was referred to by me at the recent discussion upon injuries of the jaws at the Royal Society of Medicine. I am, Sir, yours faithfully, W. WARWICK JAMES.

Park-crescent, Portland-place, W., June?27th, 1916.

\section{ENTERIC FEVERS IN THE TROPICS: A POINT IN NOMENCLATURE.}

\section{To the Editor of THE LANCET.}

SIR,-With reference to the slight change which will be made in the "heading" of the section referring to typhoid and paratyphoid fevers in the August number of the Tropical Diseases Bulietin it may be safely stated that the medical profession is not satisfied with the present classifieation of the "typhoid fevers" or with that of the bacilli which cause the separate infections. There is a fairly well marked group of " enteric fevers" having certain features in common, and if those diseases are grouped under the word " enteric" the bacilli naturally fall into a genus "enterica" with : Enterica typhosa $=B$. typhosus, E. mitis $=B$. paratyphosus A and $E$. icteriformis $=B$. paratyphosus $B$. To adopt any such change of nomenclature without the consent of a majority would only create further confusion. The present suggestion is made with a view to attracting attention to an unsatisfactory state of things.

I am, Sir, yours faithfully,

J. H. TULL WALSH,

Kingston Hill, July 4th, 1916. Lieutenant-Colonel, I.M.S. (retd.), 